\title{
Freedom of Political Communication in Australia: The Aid/Watch Case
}

\section{Introduction}

The right to freedom of political communication is central to democratic life - without it, representative democracy is seriously debilitated. In Australia its existence rests on the High Court interpretation of the Australian Constitution, and its extension across political life is subject to case law. Only if a case is brought to the High Court and won on the basis of the 'implied' freedom, can it come to life as a meaningful entitlement.

Consequently, many aspects of Australian political expression remain severely curtailed. One example is the mainstream media - where freedom of political communication is deeply compromised by the concentration of media ownership. Another is in the field of political expression, where access to public space for political debate is routinely denied, as most recently demonstrated in the silencing of the 'occupy' movement, deemed a public nuisance.

This Special Issue of the Cosmopolitan Civil Societies Journal deals with a recently successful initiative to claim freedom of political communication, in the arena of charitable advocacy. Historically, charities have been banned from having a dominant political purpose. With the 2010 Aid/Watch High Court judgement, that ban has been lifted.

The judgement has wide implications for political life in Australia. Remarkably, the High Court stated that " "agitation” for legislative and political change' is now protected under the Australian Constitution. Charities, indeed any grouping in Australia, have the right to participate in political debate and agitate for political change, as part of the system of representative democracy.

The Special Issue addresses several aspects of the case.

First, George Williams, from the Gilbert and Tobin Centre of Public Law at UNSW, covers the constitutional implications, arguing that any attempt to curtail freedom of political speech and freedom of political 'agitation' for charities can now be 'struck down' by the High Court as unconstitutional.

Two lawyers in the case, Giri Sivaraman and David Barnden, from Maurice Blackburn, likewise stress the constitutional aspects, also arguing the judgement extends protection to public debate concerning the extra-territorial impacts of Australian government policy, in this case as relating to overseas aid.

Fiona Martin, from the Australian School of Taxation at UNSW, outlines the pre-existing stipulation that advocacy could only be a means of realising non-political charitable goals. A sharp contrast is drawn with the Aid/Watch judgement, that defines 'the generation by lawful means of public debate' as having intrinsic public benefit, and thus to be in itself a charitable purpose. Again, Martin stresses the constitutional basis for the judgement.

Matthew Harding, from the University of Melbourne Law School, undertakes a forensic interpretation of the judgement, seeking its limits. He highlights the question of what constitutes 
'public debate', outlining how the judgement protects 'agitation', including campaigning and activism as undertaken by Aid/Watch, as a key component of representative democracy, but does not extend protection to lobbying groups or political parties.

Finally, myself, James Goodman, from the Cosmopolitan Civil Societies Research Centre, at the University of Technology, Sydney and long-time member of the Aid/Watch Committee of Management, offers an 'inside' account of the Aid/Watch case from 2006 to 2011. My objective in this lengthy narrative is to map the process of translating across legal and political activisms in realising political agency, and thus in extending the 'politics of rights' in Australia.

We are left with the broader implications. Harding comments that charity law is 'in many ways the centrepiece of civil society regulation in Australia'. This begs the question of what impacts the judgement will indeed have on civil society - both for charities and more widely.

The right to 'agitation' defined in the Aid/Watch case has already being taken up by lawyers contesting the use of council by-laws against the recent 'Occupy' protests, with cases now filed and pending in the Federal Courts, both in Melbourne and Sydney.

If the activism of Aid/Watch is constitutionally protected, then why not the activism of 'Occupy'? As George Williams states in this Special Issue, the right to freedom of communication now extends to the 'provocation of public debate with a view to generating support for legal and policy change'. This is exactly what the Occupy protest was undertaking. 